Christina Fogtmann \& Stine Kern Hansen

\title{
Faktorer i anmelderiet - diskussionsreferat
}

Dette er en emnebaseret opsummering af de diskussioner, der fandt sted efter hvert enkelt indlæg samt i den afsluttende debat.

Som indlæggene i forumsektionen afspejler, er faktorerne, der spiller ind på anmeldelsen, mange og netværket mellem dem komplekst. Det har vi forsøgt at indfange i nedenstående illustration:



$\mathrm{Vi}$ vil arbejde os igennem illustrationen og dermed vise problemerne $\mathrm{i}$ det komplekse forhold faktorerne imellem. I den klassiske kommunikationsmodel kan anmeldelsen ses som det objekt, der sendes fra afsenderen (anmelderen) til modtageren (læseren), og kommunikationsmodellen er kernen i vores illustration.

Et forhold i modellen, der blev nævnt flere gange, er kravet til formidling. Anmeldelsen skal formidle stof på en let tilgængelig måde og 


\section{6}

må gerne samtidig være morsom - jo længere anmeldelsen er, jo sjovere skal den være! Anmelderen skal dog ikke bare være morsom, ideelt set skal han også udvise seriøsitet og loyalitet over for læseren. Fordi anmeldelsen fungerer som en handlingsanvisning for læseren - læs eller lad være - skal anmelderen vurdere objektet i sig selv uden hensyntagen til andre faktorer, såsom anmelderens forhold til forfatter eller anmelderens egne aktiviteter. Anmelderen skal være subjektiv på en objektiv måde.

Selv om stort set alle tilsluttede sig det synspunkt, at anmelderen primært skal være loyal over for læseren, kom det frem, at det i praksis ofte ikke lader sig gøre at se bort fra anmelderens relationer til de andre faktorer. I relationen mellem anmelderen og forfatteren, kan det f.eks. være svært ikke at tage hensyn til, at forfatteren er anmelderens ekskone, eller at anmelderen selv arbejder med et projekt, der minder om det, han anmelder (et indirekte forhold mellem forfatter og objekt).

Et spørgsmål, der blev diskuteret meget, var, om forfatteren skal have lov til at se anmeldelsen, inden den bliver trykt. Mens Anne Flindt Christensen nev sig i armen, blev der fremført forskellige holdninger hertil. Mange mente, at loyaliteten over for læseren kræver, at anmeldelsen forbliver en autonom størrelse, som forfatterne ikke skal have mulighed for at påvirke. Specielt $\mathrm{i}$ tidsskrifter (modsat dagspressen) kan det dog være frugtbart at lade forfatteren læse anmeldelsen med henblik på at give forfatteren mulighed for at reagere på den og dermed starte en debat. Endvidere kan en situation, hvor forfatteren for lov til at foretage forståelsesrettelser i anmeldelsen være til læserens fordel, idet anmeldelsen da vil gengive forfatterens synspunkter, som de var intenderet. Der var dog ikke enighed om, at dette udelukkende er til læserens fordel; er der forståelsesvanskeligheder i bogen, bør dette fremgå af anmeldelsen, således at loyaliteten over for læseren bibeholdes. Den generelle holdning var imidlertid at se anmeldelsen som en autonom størrelse; den står ikke til forhandling!

Der eksisterer også et forhold mellem anmelder og læser, der går uden om anmeldelsen, nemlig i de tilfælde, hvor anmelderen kan komme til at fremstå som en autoritet. Inden for dagbladene er det et kendt fænomen, at læseren følger anmelderen uafhængigt af det anmeldte. Dette kan være på grund af enten faglig eller formidlingsmæssig kompetence. Følgelig stiller læseren en forventning til anmelderen om konsistens i den forstand, at han er tro mod sine grundholdninger. 
Anmelderens autoritet har også betydning for samspillet mellem anmelder, organ, objekt og forlag. På dagbladsredaktionerne er proceduren ofte sådan, at forlagene sender bøger til redaktøren, der så udvælger både bøger til anmeldelse og anmelder. Er anmelderen imidlertid en stor autoritet, kan forholdene ændres, således at anmelderen selv har mulighed for at foreslå bøger til anmeldelse, som ikke normalt falder under dagspressens redaktionelle linie.

På tidsskriftsredaktionerne kan proceduren variere mellem, at forfatteren sender et eksemplar af sin bog til tidsskriftet, og at kommunikationen går gennem et forlag, der så enten forespørger eller bare sender et anmeldereksemplar til tidsskriftet. Det sidste vil være tilfældet for et veletableret tidsskrift, mens det for det nyopstartede er svært at vide, om man er helt opdateret mht. relevante nyudgivelser. Bl.a. på baggrund af dette blev det fremført, hvor vigtigt det er, at forlaget holder redaktionerne informeret om nye publikationer. På den anden side er det af stor betydning for det gode forhold mellem redaktion og forlag, at redaktionen sender et eksemplar af den publicerede anmeldelse til forlaget, hvis forlaget ønsker det.

Når redaktøren på tidsskriftet modtager en bog, kan det være problematisk for ham at finde en anmelder. Redaktøren skal have etableret en stab af kompetente anmeldere, og det kan han gøre ved at skabe et netværk af venner og venners venner i ind- og udland. Det er vigtigt at være klar over, at redaktøren ved valg af anmelder samtidig bestemmer anmeldelsens profil. I paneldebatten var der et tydeligt eksempel på dette. I det $\varnothing$ jeblik $N y S$ beder Asgerd Gudiksen om at anmelde Pia Jarvads bog, er de allerede klar over, at der dermed lægges en bestemt vinkel på bogen.

Når man udvælger bøger til anmeldelse, er redaktør og anmelder tvunget til at tage stilling til nyhedskriteriet. Redaktøren i form af, hvor lang tid der må gå fra publicering til anmeldelsestidspunktet; anmelderen gennem anmeldelsens udformning. På tværs af organerne kan der ikke opstilles et generelt nyhedskriterie, idet tidsskriftet arbejder under helt andre tidsparametre end dagspressen: Mens dagspressen har en grænse på uger, har tidsskriftet en grænse på år.

Dagspressen synes at have flere muligheder for, på en fornuftig måde, at inddrage den bog, der har overskredet tidsgrænsen, nemlig ved at overskride anmeldelsesgenren. Eksempelvis kan man skabe hybrider mellem anmeldelsen og artiklen, så man introducerer og præsenterer, 
mere end man decideret anmelder en bog. En pointe er her, at der i højere grad fokuseres på bogens emne i modsætning til at vurdere den $\mathrm{i}$ sig selv. Således kan man forestille sig, at bogens emne uafhængigt af bogen er blevet aktuelt, eller at bogen kan relateres til en nyere publicering af samme forfatter eller inden for samme emne.

Som følge af den nævnte genreoverskridelse bliver det nødvendigt at få klarlagt anmeldelsens mange mulige typer inden for genren anmeldelse. Tilsyneladende vil de mulige typer dog være forskellige i de to organer. I dagspressen har man som nævnt mulighed for at lave hybrider mellem anmeldelsen og andre genrer, og anmeldelsen kan gives en helt anden udformning end den "traditionelle" anmeldelse - om end de nødvendige og tilstrækkelige betingelser for denne ikke lader sig eksplicitere. Det forekommer os, at man ikke udnytter nye hybridmuligheder i tidsskriftet, såfremt dette organ lader sådanne typer realisere. Mens man altså i dagspressen i princippet kan skabe hybrider ad libitum, var alle enige om, at for at teksten skal falde under anmeldelsesgenren, må der i hvert fald være én nødvendig komponent, nemlig vurderingen. Dette forhold gælder også i tidsskriftet, men i tidsskriftet lader det sig i højere grad gøre at definere nogle typer - sandsynligvis fordi man ikke gør brug af nye genrekombinationer. Eksempelvis arbejder Hermes med følgende tre typer: Den korte anmeldelse på ca. to sider, den middellange på ca. seks og endelig review article.

Det viste sig på seminaret, at definitionen af review article varierer. I overensstemmelse med Hermes vil vi ved review article forstå en anmeldelse, der tager udgangspunkt i et emne, som objektet præsenterer, for at diskutere og kontekstualisere det. Også her gælder det, at teksten for at kunne kategoriseres som anmeldelse må rumme en vurdering om ikke af hele værket, så af objektets måde at forholde sig på til det diskuterede emne.

Begrebsforvirringen omkring review article opstod delvis, fordi man havde svært ved at skelne review article fra survey article. Det stod klart, at der var behov for to begreber til at dække over henholdsvis det, vi nu har defineret som review article, og på den anden side en anmeldelse, der sammenligner og vurderer flere objekter på baggrund af deres emne. Som følge af ovenstående vil vi lade survey article dække over sidstnævnte type.

Omtale, annotering og note blev også nævnt som mulige anmeldelsestyper, men oftest vil de have en tendens til at falde uden for anmel- 
delsesgenren, idet den nødvendige komponent, vurderingen, mangler. Grunden til dette er naturligvis deres længde, der kan være helt ned til ganske få linier.

På baggrund af de nævnte anmeldelsestyper kan man tale om behovet for dem set ud fra både forfatter, forlag og læsers synsvinkel. Det er klart, at både forfatter og forlag har en interesse i at få omtalt bogen så mange gange som muligt - anmeldelsen som reklame. Det blev fremført, at mht. læserens behov er den middellange anmeldelse i Hermes' tre-deling overflødig. Læseren har enten brug for en kort handlingsvejledende oplysning eller en lang uddybende anmeldelse, der sætter bogen ind i den videnskabelige tradition, den tilhører. Mange mente dog, at de fleste læsere vil foretrække den middellange anmeldelse.

I denne forbindelse vil det være relevant at overveje, hvilket objekt der anmeldes og dets betydning for anmeldelsens udformning og længde (jf. illustrationen). Ser man f.eks. på anmeldelse af en ordbog og anmeldelse af en almindelig videnskabelig bog, viser det sig, at læseren har helt forskellige behov alt efter, hvilken anmeldelse han læser. Ordbogsanmeldelsen fungerer oftest som udelukkende handlingsanvisende - er det den ordbog, jeg skal slå op i næste gang? Således bliver behovet for typen review article kraftigt reduceret.

Ser man derimod på anmeldelsen af den almindelige videnskabelige bog, kan læseren både have interesse i den handlingsvejledende funktion og den fagligt oplysende og perspektiverende. Her bliver review article altså langt mere relevant.

Man kan spørge sig selv, om det er muligt at formulere en generel anmeldelses politik, der kan tage hensyn til det komplekse billede, som vores illustration afspejler. Ved anmeldelsespolitik forstår vi et sæt ekspliciterede regler om,

- hvor høj prioritet anmelderiet skal have i forhold til andet stof

- hvorledes genren skal defineres

- hvilken procedure der er for kommunikationen mellem forlag og redaktion

- hvilken procedure der er for udvælgelse af bøger og anmeldere

- hvorvidt der foreligger en manual for udarbejdelse af anmeldelsen 
Det synes ikke at være muligt at fastsætte en global anmeldelsespolitik. Man kunne dog forestille sig, at det kunne lade sig gøre at have en sådan på lokalt plan, dvs. på den enkelte redaktion. Er dette muligt, vil det være en fordel for anmelderen, idet han igennem den eksplicitte anmeldelsespolitik får det nødvendige kendskab til den redaktionelle linie. På den måde lettes også redaktørens arbejde. Med manualen som en del af anmeldelsespolitikken bliver selve strukturen i anmeldelserne ens. Det betyder, at læseren bliver fortrolig med anmeldelsens overordnede struktur, hvilket må antages at lette læseprocessen.

Alligevel mødte selve tanken om en anmeldelsespolitik som et regelsat på det lokale plan modstand på seminaret. De fleste (redaktører) anså det for usandsynligt, at de ville kunne efterleve en fastsat politik. Men ingen var uenige $i$, at der er store erkendelsesmæssige gevinster ved at formulere en anmeldelsespolitik i form af retningslinier - og gennem en sådan bevidstgørelsesproces kan der endda opstå gode ideer til forbedring af den redaktionelle praksis på alle niveauer. 